\title{
Model Systems for Cardiovascular Regenerative Biology
}

\author{
Jessica C. Garbern ${ }^{1}$, Christine L. Mummery ${ }^{2}$, and Richard T. Lee ${ }^{3}$ \\ ${ }^{1}$ Boston Children's Hospital, Boston, Massachusetts 02115 \\ ${ }^{2}$ Department of Anatomy \& Embryology, Leiden University Medical Center, 2300 RC Leiden, The Netherlands \\ ${ }^{3}$ Brigham and Women's Hospital and Partners Research Facility, Cambridge, Massachusetts 02139 \\ Correspondence: rlee@partners.org
}

There is an urgent clinical need to develop new therapeutic approaches to treat heart failure, but the biology of cardiovascular regeneration is complex. Model systems are required to advance our understanding of biological mechanisms of cardiac regeneration as well as to test therapeutic approaches to regenerate tissue and restore cardiac function following injury. An ideal model system should be inexpensive, easily manipulated, easily reproducible, physiologically representative of human disease, and ethically sound. In this review, we discuss computational, cell-based, tissue, and animal models that have been used to elucidate mechanisms of cardiovascular regenerative biology or to test proposed therapeutic methods to restore cardiac function following disease or injury.

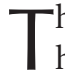
he concept of regenerating human tissues has permeated folklore since ancient times. Research in regenerative biology has been documented as early as the 1680s with the observation that lizards can regenerate their tails after amputation (Singh et al. 2010). Many examples of regeneration in higher organisms are well characterized, although why some tissues regenerate and others cannot remains unclear at the molecular level (Brockes and Kumar 2008).

With cardiovascular disease the leading cause of death worldwide (World Health Organization 2011), there is widespread enthusiasm for cardiac regeneration. Although adult human hearts were once thought to be senescent organs incapable of regeneration, recent evidence supporting the existence of resident cardiac progen- itor cells and the ability of fully differentiated cardiomyocytes to divide has shifted our view of human cardiac regenerative potential (Buja and Vela 2008; Bergmann et al. 2009). However, our incomplete understanding of cardiac regenerative behavior has limited our ability to develop effective therapeutic approaches to restore cardiac function to injured tissue.

Model systems are necessary both to better understand biological mechanisms of cardiac regeneration as well as to develop therapeutic approaches to regenerate and restore function to human cardiovascular tissue following injury. An ideal model system should be inexpensive, easily manipulated, easily reproducible, and ethically sound; furthermore, it should recapitulate human disease pathophysiology.

Editors: Margaret Buckingham, Christine L. Mummery, and Kenneth R. Chien

Additional Perspectives on Biology of Heart Disease available at www.perspectivesinmedicine.org

Copyright (C) 2013 Cold Spring Harbor Laboratory Press; all rights reserved; doi: 10.1101/cshperspect.a014019

Cite this article as Cold Spring Harb Perspect Med 2013;3:a014019 
J.C. Garbern et al.

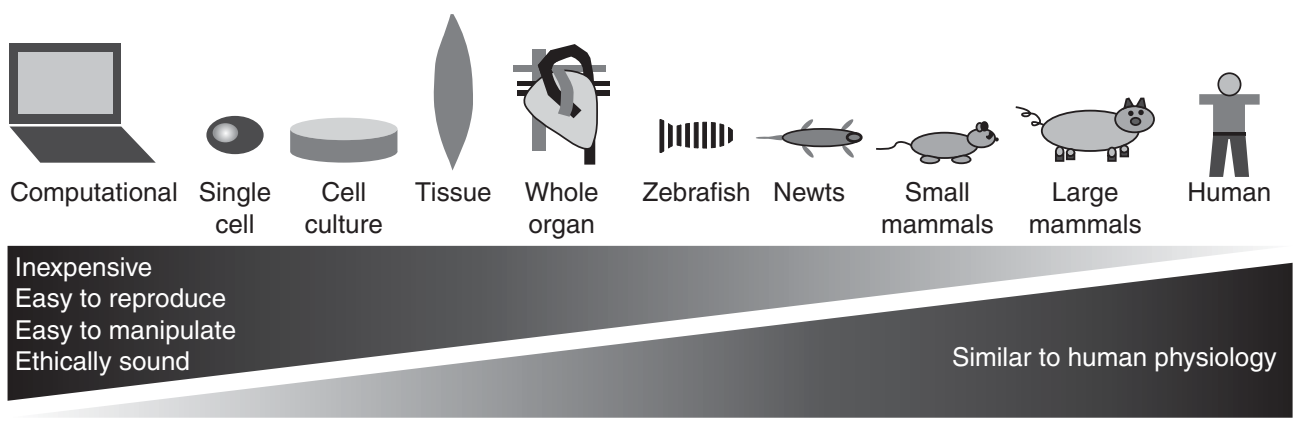

Figure 1. Schematic of model systems for cardiovascular regeneration.

Although no universal model has been identified that meets all criteria, many model systems have been developed that capture different aspects of development, regeneration, and disease (Fig. 1). Some of these models are more useful for understanding the mechanisms of cardiac regeneration, whereas others are more useful as disease models for testing regenerative approaches.

In this review, we discuss computational, cell-based, tissue, and animal models that have been used in the study of cardiovascular regenerative biology or in the testing of therapeutic approaches to restore cardiac function following disease or injury.

\section{COMPUTATIONAL}

Computational and mathematical models offer an advantage over traditional experimental models in their ability to test a multitude of parameters efficiently. For example, computational models have predicted the effect of bone marrow stem cell transplantation on fibrosis in the cardiomyopathy associated with Chagas disease (Galvao et al. 2008) or platelet activation after implantation of a bioprosthetic heart valve (Sirois and Sun 2010). The McCulloch group has published diverse computational models to study cardiac behavior, ranging from a model of focal myofibril disarray to represent regional septal dysfunction as seen in hypertrophic cardiomyopathy (Usyk et al. 2001), to the effect of biventricular pacing on left ventricular function (Kerckhoffs et al. 2009) and the influence of myosin regulatory proteins on myosin kinetics (Sheikh et al. 2012).

Although computational modeling offers the advantage of efficiency, the models are inherently limited in their abilities to predict biological processes. By necessity, computational models must simplify biological systems into generalizable rules (Peirce 2008). Mathematical models cannot incorporate every possible confounding factor; therefore, data must be confirmed in living cells or organisms. Because many factors in regeneration are poorly understood, experimental models are irreplaceable in cardiac regeneration research.

\section{IN VITRO MODELS}

In vitro experimental models allow the researcher to study a biological system while still retaining a high level of control over the experimental parameters. Examples of in vitro models used in cardiac regenerative research include single cell, cell culture, tissue, whole heart, and microfluidic models.

\section{Single Cell}

Testing the electromechanical properties of single cardiomyocytes (CMs) has been crucial to our understanding of cardiac physiology. The mechanical properties of individual CMs can be influenced by factors such as stress, strain, substrate chemistry, stiffness, and geometry (Curtis and Russell 2011). Methods such as atomic force microscopy, use of force 
Model Systems for Cardiac Regeneration

transducers, or optical methods have been developed to quantify the mechanical properties of individual cells (Curtis and Russell 2011).

The electrophysiology of a single CM can be evaluated using the patch-clamp technique (Cerbai et al. 2000). By attaching a micropipette to the cell membrane of a single cell, one can measure the ionic current through a single ion channel (Liem et al. 1995). The patch-clamp technique can characterize the phenotype of CMs differentiated from embryonic stem cells (ESCs) (Maltsev et al. 1994; Mummery et al. 2002, 2003; Sartiani et al. 2007). Of note, however, isolated cardiomyocytes can behave somewhat differently from cells in groups and may show different responses to drugs.

\section{Two-Dimensional (2D) Culture}

Although experiments in single cells provide valuable mechanistic data, particularly on the presence and nature of ion channels present, cells in the native heart function as a syncytium, and methods that investigate the behavior of groups of cells come closer to the in vivo state. CMs grown in $2 \mathrm{D}$ culture systems have been used to elucidate molecular signaling pathways (von Gise et al. 2012), assess drug-induced cardiotoxicity (Guo et al. 2011), and evaluate gene therapy approaches ( $\mathrm{Lu}$ et al. 2012). Two-dimensional cultures can also be examined electrically using microelectrode arrays (Braam et al. 2010) or voltage-sensitive dyes (Herron et al. 2012). More complicated architecture is also possible using 2D culture techniques. CMs grown in 2D culture on a temperature-responsive surface (to facilitate release of cell sheets in response to temperature change) have also been layered into three-dimensional (3D) structures to create myocardial patches capable of pulsating spontaneously (Shimizu et al. 2002). When implanted into rats as a myocardial patch after a myocardial infarct, the fractional shortening and ejection fraction of the infarcted hearts were significantly higher at 2, 4, and 8 wk after implantation compared with control (Miyagawa et al. 2005). These results may indicate a route to future therapies.

\section{Three-Dimensional (3D) Culture}

Cells can also be grown in 3D cultures, scaffolds, or matrices, which is a common tissue engineering approach (Zimmermann et al. 2006; Ye and Black 2011). Cell phenotype can be dramatically affected by the culture geometry; for example, chick CMs grown in 3D cultures have more mitochondria, display more cell-cell junctions, show more spontaneous contractions, and express a greater abundance of proteins found in mature CMs (e.g., desmin, $\alpha$-actin, and cadherin) when compared with CMs grown in 2D cultures (Soares et al. 2012).

Three-dimensional systems have also been used as scaffolds for tissue engineering. Biomaterials used for the construction of early 3D cardiac scaffolds include alginate (Leor et al. 2000), collagen (Kofidis et al. 2003), and gelatin ( $\mathrm{Li}$ et al. 2000), although these materials may not easily support high cell survival rates with increased thickness (Shimizu et al. 2002). More recent scaffolds that aim to mimic the natural extracellular matrix (ECM) have been tested, such as silk fibroin (Patra et al. 2012), polyurethanes (Siepe et al. 2006), electrospun poly- $\varepsilon$ caprolactone (Shin et al. 2004), or decellularized ECM (Singelyn et al. 2009). Scaffold-free approaches (Stevens et al. 2009) avoid the potential complications of implanting a foreign material into the body if being used for transplantation, although they are limited in their geometric design. Together these engineering approaches not only provide new opportunities for therapy but, because they also closely mimic intact (human) myocardium, they also can serve as models for normal heart physiology. Engineered healthy cardiac tissues can be used to analyze responses to cardiotoxic drugs as a pharmacological screening tool, whereas tissues created using diseased cardiomyocytes can simulate cardiac pathophysiology and the responses of diseased heart tissue to drugs or other stimuli.

\section{Coculture}

Although cultures involving a single cell type provide a simplified model for scientific study, they do not adequately represent the complex microenvironment found in a multicellu- 
J.C. Garbern et al.

lar tissue. Growing cells in coculture simulates the cellular cross talk that occurs between different cell types (Kirkpatrick et al. 2011).

Mouse ESCs cocultured with cardiac fibroblasts display a greater percentage of beating embryoid bodies and increased expression of the cardiac markers GATA4, ANF, and CX43 compared with ESCs grown alone (Ou et al. 2011). In one study, scaffold-free cardiac patches made from human ESCs allowed to self-aggregate on a rotating orbital shaker were found to have necrotic centers by $8 \mathrm{~d}$ because of lack of vascularization (Stevens et al. 2009). However, when human ESCs were combined with human umbilical-vein endothelial cells and mouse embryonic fibroblasts, vascular networks formed that morphologically resembled capillaries, and CM proliferation was enhanced (Stevens et al. 2009).

\section{Microfluidic Systems}

Microfabrication using soft lithography techniques has become a widely applied technology to study biological environments on the micrometer scale (van der Meer et al. 2009; Chung et al. 2012). Microfluidic or "lab-on-a-chip" devices offer precise control over the cellular microenvironment, lending themselves well to the study of cell behavior or formation of scaffolds with well-defined architecture.

Microfluidic systems have been constructed to study the electrophysiology of single CMs in microfabricated patch-clamp devices (IonescuZanetti et al. 2005), or cell-cell signaling between pairs of CMs (Klauke et al. 2007). Microfabrication techniques can also be used to create well-defined 3D scaffolds for tissue engineering applications (Fidkowski et al. 2005; Engelmayr et al. 2008; Zhang et al. 2011). These advanced structures provide opportunities for studying normal heart physiology and creating disease models and platforms for drug discovery and safety pharmacology (Grosberg et al. 2011).

\section{Cell Sources}

Cell sources for single cell, cell culture, or microfluidic studies include cell lines, primary cells, and stem/progenitor cells. The advantages and disadvantages of these cell types are summarized below.

\section{Cell Lines}

Cell lines can be passaged indefinitely while maintaining their phenotypic characteristics, and therefore they offer a significant advantage regarding ease of use. Unfortunately, unlike transformed tumor cells, mammalian cardiac cells are not prone to divide in culture, and few cardiac cell lines have been developed. Among these are lines derived from mouse and human cardiac sarcomas. Although using immortal, transformed cell lines is more convenient than harvesting primary cells, the process of transformation changes the basic properties of cardiomyocytes that are highly relevant to regenerative medicine and cardiac biology.

The AT-1 tumor line was developed in transgenic mice with a fusion between the SV40 T antigen oncoprotein and the promoter region for atrial natriuretic factor (ANF) (Field 1988). AT- 1 cells are maintained as a tumor line using a syngeneic mouse host. They are capable of survival in culture while retaining a CM phenotype; however, they cannot be serially passaged or successfully recovered after freezing (Claycomb et al. 1998).

The HL-1 mouse CM cell line was isolated from AT-1 cells by systematic modification of the culture environment (Claycomb et al. 1998). It was the first mammalian CM cell line described in the literature that could be frozen and recovered, passaged indefinitely, and maintain phenotypic characteristics such as contractility and expression of adult CM protein isoforms including $\alpha$-cardiac actin, $\alpha$-myosin heavy chain (MHC), and connexin43 (Claycomb et al. 1998). HL-1 cells have proven to be a versatile model system (White et al. 2004), used to investigate cell signaling (Kitta et al. 2001), electrophysiology (Sartiani et al. 2002), and the effects of hypoxia (Nguyen and Claycomb 1999).

The immortalized human ventricular $\mathrm{AC}$ cell line was developed using a method involving fusion of primary ventricular CMs with an 
Model Systems for Cardiac Regeneration

SV40-transformed fibroblast cell line (Davidson et al. 2005). AC cells express adult CM markers such as $\alpha$-cardiac actin and $\beta$-myosin heavy chain, show ultrastructural similarities to primary CMs with the presence of myofibrils, and have functional gap junctions. However, AC cells are unable to maintain a physiologically relevant action potential, and the cells are not contractile, likely because of the lack of myofibril organization (Davidson et al. 2005), making their relevance as a cardiac model unclear.

\section{Primary Cells}

Although primary cardiomyocyte isolation can be expensive and time-consuming, primary cells are considered to be more representative of cell behavior in vivo compared with cell lines (Eglen and Reisine 2011). Adult mammalian CMs have been considered to be postmitotic, having undergone an incomplete cycle of cell division during the neonatal period, resulting in CMs that are binucleated or multinucleated (Ausoni and Sartore 2009; Walsh et al. 2010). Primary CMs can be isolated from cardiac tissue (e.g., obtained via surgery or tissue biopsy) by use of enzymatic digestion of the ECM and isolation of cells by mechanical methods (Mitcheson et al. 1998; Xu and Colecraft 2009).

Primary CMs from multiple species (e.g., chick, human, mouse, rat) have contributed extensively to our understanding of the electromechanical properties of the heart (Ellingsen et al. 1993; Mitcheson et al. 1998). Examples of recent studies have used primary mouse CMs to investigate cell signaling after myocardial infarction (Raake et al. 2012), gene expression in response to hypoxia in rat CMs (Kim et al. 2012), or the effect of the cardiovascular hormone relaxin on the maturation of primary neonatal mouse CMs (Nistri et al. 2012). In addition to "working" CMs, whose primary function is to contract, CMs that contribute to the conduction system (sinoatrial and atrioventricular nodes and the ventricular conduction system) have been isolated and characterized (Gourdie et al. 1995; Bakker et al. 2010; Ye Sheng et al. 2011).

\section{Stem/Progenitor Cells}

Stem and progenitor cells are discussed in more detail in Laugwitz (2013), but are introduced here in the context of their potential for cardiovascular regeneration. Pluripotent stem cells and some types of progenitor cells in postnatal tissues retain the ability to self-replicate as well as differentiate into a variety of other cell types, making them highly attractive targets for research in regenerative medicine and the development of therapies to restore tissue function. Various types of cardiac progenitor cells have been described as isolated from the heart (Passier et al. 2008), but only a few have been shown to form bona fide cardiomyocytes and only then after addition of global demethylating reagents like 5-azacytidine and transforming growth factor $\beta$ (Goumans et al. 2008).

Multipotent stem cells and progenitor cells can be derived from embryonic, fetal (also umbilical cord [Breymann et al. 2006] and amniotic fluid [Walther et al. 2009]), and adult tissues (including hematopoietic, mesenchymal/ stromal, and heart) (Bernstein and Srivastava 2012). Pluripotent stem cells derived from embryos (embryonic stem cells, ESCs) (Vidarsson et al. 2010) or induced by reprogramming somatic cells (inducible pluripotent stem [iPS] cells) (Yoshida and Yamanaka 2011) have the potential to develop into CMs and other supporting cell types such as fibroblasts and endothelial cells, although their biology is still not completely understood.

The identification of adult cardiac progenitor cells in mammals has resulted in a paradigm shift to a view that the heart harbors stem cell populations that could contribute to cardiac regeneration (Beltrami et al. 2003; Oh et al. 2003; Messina et al. 2004). More recent studies suggest that there may be several progenitor cell types expressing different stem cell markers (Sca-1, c-kit, isl-1) capable of self-renewal and differentiation into cardiac cells, although the relationship between these different cell types remains unclear (Barile et al. 2007; Smart et al. 2011; van Vliet et al. 2012). Methods for both primary isolation as well as serial passaging of some of these human progenitor cells 
J.C. Garbern et al.

have been described (Smith et al. 2007; Smits et al. 2009).

\section{Tissue Models}

The electromechanical properties of cardiac tissue are dependent on the $3 \mathrm{D}$ structure of the heart. Isolated tissue models have been valuable because these properties are difficult to adequately represent in cell culture studies, and in vivo studies can be logistically challenging and costly. For instance, a biaxial mechanical testing device was developed to evaluate the effect of strain rate on isolated native porcine mitral valves (Grashow et al. 2006). In addition, right ventricular free walls isolated from guinea pig hearts were attached to microelectrodes then used to study the effect of various conditions (e.g., hypoxia, acidosis, drug exposure) on arrhythmogenic behavior (Ferrier and Howlett 2005).

Bioreactors that impose mechanical or electrical stimuli on isolated tissue components may also be important in the proper development of regenerated tissues. For example, engineered human myocardium grown under conditions of cyclic stress resulted in increased CM hypertrophy and proliferation compared with tissues grown under static conditions (Tulloch et al. 2011). Testing of isolated tissues in such devices will be necessary to validate the electromechanical properties and stability of bioengineered tissues should they be intended for human use.

\section{Whole Heart/Ex Vivo Models}

Whole organ explants allow evaluation of cardiac function ex vivo. The Langendorff technique involves isolation of the whole heart from an animal followed by attachment to a fluid reservoir to simulate blood flow through the heart (Neely et al. 1973; Vidavalur et al. 2008). Rats injected with induced bone marrow mesenchymal stem cells (BMSCs) compared with vehicle show improved coronary blood flow and improved left ventricular end diastolic pressure, indicating smaller infarct size when evaluated by the Langendorff model ( $\mathrm{Li}$ et al. 2012). In another study, a modified Langen- dorff apparatus was used to decellularize whole pig hearts, leaving behind the anatomically correct extracellular matrix, which could potentially be used as a scaffold for whole heart tissue engineering (Weymann et al. 2011).

\section{IN VIVO MODELS}

Although computational and in vitro models can provide valuable information regarding cardiac behavior under carefully controlled experimental conditions, there is no replacement for in vivo models to understand the complex behavior of the heart within a living organism.

\section{Noncardiac Regenerative Models}

Although the focus of this article is cardiac models for the study of cardiac regeneration, noncardiac animal models can provide clues to cardiac regenerative biology using methods that are less expensive or have fewer logistical or technical challenges.

Invertebrates such as hydra or planarians retain the ability to completely regenerate following injury even after amputation of more than half of their bodies (Newmark and Sanchez Alvarado 2002; Sanchez Alvarado and Tsonis 2006). Although these invertebrate species have much simpler architectures compared with vertebrate species, their ability to undergo complete regeneration after amputation is impressive, and as such they represent useful model systems to better understand regenerative biology and stem cell behavior.

Examples of noncardiac mammalian regeneration also provide insight into potential mechanisms of cardiac regeneration. For instance, regeneration of skeletal muscle following injury can act as a model for myocyte regeneration in more easily accessible tissue (Borisov 1999). In addition, although mammalian heart regeneration is limited, studying model organs such as the skin (Palatinus et al. 2010) or liver (Badylak et al. 2012) that do continue to regenerate into adulthood in humans, can provide us with clues on the underlying principles of regeneration of relevance to the heart. 


\section{Cardiac Regenerative Models}

Among vertebrates, zebrafish and urodele amphibians display an intrinsic ability for cardiac regeneration following significant myocardial injury. Although adult mammals have not shown an endogenous capability to fully regenerate heart tissue following severe injury, small and large animal mammalian models have been studied extensively with the goal of finding therapeutic interventions to effectively regenerate the heart following injury.

\section{Zebrafish}

Significant lessons can be gained from studying the regenerative potential of the two-chamber (one atrium, one ventricle) hearts of teleost fish, such as the zebrafish. Adult zebrafish are able to fully regenerate cardiac tissue after $\sim 20 \%$ of the heart is transected from the apex (Poss et al. 2002; Raya et al. 2003). The site of injury initially clots off followed by replacement of red blood cells with fibrin. However, within the first month after injury, the fibrin is quickly replaced by cardiac myofibers, and by 2 mo postinjury, the cardiac tissue is virtually indistinguishable from the hearts of sham-operated controls by both gross inspection and histology (Poss et al. 2002).

Multiple hypotheses have been proposed as to the source of the regenerated CMs, including (1) a normally dormant progenitor cell population is recruited after injury to proliferate; (2) mature CMs undergo cell division; or (3) mature CMs dedifferentiate into a progenitor-like population that then undergoes proliferation (Poss 2007; Steinhauser and Lee 2011). There is evidence to suggest that all three of these mechanisms may contribute to heart regeneration in zebrafish, although more recent studies suggest that the predominant contributor to regenerated myocardium in zebrafish is dedifferentiated CMs (Lien et al. 2012; Jopling et al. 2010).

Differentiated CMs near the site of amputation showed increased DNA synthesis compared with cells further from the amputation plane, as indicated by differential incorporation of bromodeoxyuridine (BrdU), with peak BrdU incorporation at $\sim 14 \mathrm{~d}$ postamputation (dpa)
(Poss et al. 2002). Initial studies proposed that the source of these proliferating CMs originated from a blastema composed of undifferentiated progenitor cells near the site of injury, which undergo differentiation into CMs and proliferate (Lepilina et al. 2006). However, more recent studies suggest that mature CMs undergo limited dedifferentiation as shown by disassembly of their sarcomeric structure (Jopling et al. 2010) and expression of gata4, a transcription factor that regulates myocardial formation during embryonic development (Kikuchi et al. 2010). In addition to CM proliferation, myocardial injury is also thought to activate the surrounding epicardium, which supplies cells that undergo an epithelial-to-mesenchymal transition to revascularize the myocardial tissue (Lepilina et al. 2006).

Zebrafish reproduce quickly with large batches of embryos, are relatively easy to maintain, and have a cardiac system that develops in a transparent environment (Poss 2007). To better represent the residual injured cells that remain after a myocardial infarction, a cryoinjury model has been proposed as an alternative to the resection model (González-Rosa and Mercader 2012). In addition, a genetic ablation model, in which death of $>60 \%$ of CMs occurs uniformly in response to expression of diphtheria toxin A chain in transgenic zebrafish, may provide a more accurate model of global heart failure compared with surgical approaches (Wang et al. 2011).

Zebrafish and mammals likely have inherent differences that allow zebrafish to regenerate myocardium, as opposed to forming scar tissue, which is the predominant response to myocardial injury in mammals (Poss 2007). Zebrafish are capable of indeterminate growth, whereby adult zebrafish can continue to grow in size through adulthood depending on the surrounding environment such as food availability and population density (Goldsmith et al. 2006). In addition, zebrafish CMs are mononucleated, smaller in size, and have a less robust contractile apparatus (Poss 2007). Further understanding of the mechanisms by which zebrafish hearts undergo myocardial regeneration will provide us with insight into potential strategies that 
J.C. Garbern et al.

could be used to influence mammalian heart regeneration.

\section{Amphibians}

Urodele amphibians, including newts and axolotl salamanders, have a remarkable ability to regenerate injured tissues including the spinal cord, brain, lens, jaw, tail, and fully functional limbs following amputation (Brockes and $\mathrm{Ku}$ mar 2002; Roy and Gatien 2008). Early studies showed that newts are capable of survival after resection of a significant portion (as high as $50 \%$ ) of apical myocardium (Becker et al. 1974) and show evidence of CM regeneration at $30 \mathrm{dpa}$ (Oberpriller and Oberpriller 1974).

The mechanism by which urodele CMs regenerate is attributed to partial dedifferentiation of adult CMs into progenitor cells (Laube et al. 2006). Interestingly, when newt CMs are implanted into a site of limb amputation, the CMs transdifferentiated into skeletal muscle or chondrocyte phenotypes, which is thought to be due to the influence of the nearby limb blastema (Laube et al. 2006). How newt CMs undergo dedifferentiation and reenter the cell cycle remains to be elucidated, but several signaling pathways have been proposed, including those involving thrombin, fibroblast growth factors, or the Bmp and Msx pathways (Singh et al.2010).

Urodeles offer several advantages as a model system for evaluation of cardiac regeneration. Embryonic development occurs externally, facilitating visualization, and embryos are available in large batches (Neff et al. 1996). They are larger than zebrafish and have a more complex cardiac structure with three chambers (two atria, one ventricle) (Singh et al. 2010). Unlike mammalian hearts, which have a high percentage of multinucleated CMs, 98\% of CMs in an uninjured newt heart are mononucleated and diploid, which may contribute to their regenerative ability and also simplifies histological analysis (Neff et al. 1996).

\section{Snake}

The heart of the Burmese python can increase in mass by $40 \%$ after consumption of a large meal to support postprandial metabolic demands (Riquelme et al. 2011). Modifications in gene expression of proteins involved in fatty acid transport were associated with alteration of the fatty acid composition of the snake plasma. When a fatty acid mixture of myristic acid, palmitic acid, and palmitoleic acid formulated to mimic snake plasma was administered to starved mice, there was a rapid and heart-specific hypertrophic response (Riquelme et al. 2011). Although hyperplasia of cardiomyocytes was not seen, this cardiac-specific hypertrophy in response to circulating factors warrants further investigation as a potential approach to augment cardiac regeneration.

\section{Small Mammals}

Small mammalian models offer a physiologically relevant system compared with fish and amphibians and are less expensive and easier to manipulate genetically compared with larger animals. Small animals such as mice, rats, hamsters, guinea pigs, and rabbits have all been used to model heart disease in humans (Hasenfuss 1998). Disease-specific animal models have been developed, for example, to study heart failure, arrhythmias, atherosclerosis, or aneurysms (Nishida et al. 2010; Zaragoza et al. 2011; Houser et al. 2012). The availability of genetically modified mouse models makes mice a valuable species in which to study cardiac regenerative biology (Zaruba and Field 2008). Being larger in size, surgical procedures can be technically easier in rats and also result in harvest of a greater quantity of CMs per heart compared with mice (Zaruba and Field 2008). In general, larger animals have slower heart rates and a cardiac physiology that more closely resembles that of humans (Table 1); therefore, rabbits and guinea pigs offer a reasonable balance between accurate physiology and cost (Hasenfuss 1998). Here we describe recent examples that show the use of these small animal models to establish evidence of myocardial regeneration in mammals as well as to test therapeutic approaches to restore cardiac function following injury.

In a genetic fate mapping study in adult mice, progenitor cells did not appear to con- 
Model Systems for Cardiac Regeneration

Table 1. Comparison of heart characteristics between species

\begin{tabular}{|c|c|c|c|c|c|}
\hline & $\begin{array}{l}\text { Number } \\
\text { of heart } \\
\text { chambers }\end{array}$ & $\begin{array}{l}\text { Average } \\
\text { heart } \\
\text { mass }(g)^{\text {a }}\end{array}$ & $\begin{array}{l}\text { Average } \\
\text { heart rate } \\
(\mathrm{bpm})^{\mathrm{b}}\end{array}$ & $\begin{array}{c}\text { Percent } \\
\text { mononucleated } \\
\mathrm{CMs}^{\mathrm{c}}\end{array}$ & Inherent regenerative potential \\
\hline Zebrafish & 2 & 0.003 & $130-180$ & 95 & $\begin{array}{l}\text { Full regeneration } 60 \mathrm{~d} \text { after amputation } \\
\text { of } \sim 20 \% \text { of apical myocardium } \\
\end{array}$ \\
\hline $\begin{array}{l}\text { Urodeles } \\
\text { (newt or } \\
\text { axolotl) }\end{array}$ & 3 & 0.05 & $20-30$ & 98 & $\begin{array}{l}\text { Full regeneration } 30-60 \mathrm{~d} \text { after } \\
\text { amputation of } \sim 10 \%-25 \% \text { of apical } \\
\text { myocardium }^{\text {e }}\end{array}$ \\
\hline Python & 3 & 1 & 20 & N.R. & $\begin{array}{l}\text { Postprandial reversible } 40 \% \text { mass } \\
\text { increase due to hypertrophy without } \\
\text { hyperplasia }^{\text {f }}\end{array}$ \\
\hline Mouse & 4 & 0.2 & $450-750$ & $\begin{array}{l}1 \mathrm{~d} \text { old: } 96 \\
\text { Adult: }<9\end{array}$ & $\begin{array}{l}\sim \text { Full regeneration } 21 \mathrm{~d} \text { after } \\
\quad \text { amputation of } \sim 15 \% \text { of apical } \\
\text { myocardium in neonatal mice }\end{array}$ \\
\hline Rat & 4 & 0.8 & $250-450$ & $\begin{array}{l}1 \mathrm{~d} \text { old: } 97 \\
10 \text { d old: } 9\end{array}$ & Minimal or N.R. \\
\hline Guinea pig & 4 & 1 & $130-330$ & N.R. & Minimal or N.R. \\
\hline Rabbit & 4 & 8 & $170-280$ & N.R. & Minimal or N.R. \\
\hline Monkey & 4 & 30 & $100-270$ & N.R. & Minimal or N.R. \\
\hline Dog & 4 & 100 & $70-140$ & 2 & Minimal or N.R. \\
\hline Pig & 4 & 200 & $70-120$ & $\sim 5$ & Minimal or N.R. \\
\hline Sheep & 4 & 200 & $70-120$ & $\begin{array}{l}4 \text { d old: } 17 \\
4-6 \text { wk old: } 8\end{array}$ & Minimal or N.R. \\
\hline Human & 4 & 300 & $60-80$ & 74 & Minimal or N.R. \\
\hline
\end{tabular}

(N.R.) Not reported.

${ }^{a}$ Larson (1978); Poupa and Lindstrom (1983); de la Grandmaison et al. (2001); Tiritilli (2001); Davis et al. (2002); RuttkayNedecky (2004); Andersen et al. (2005); Keenan and Vidal (2006); van Timmeren et al. (2008); Bunker and Laughlin (2010); Lafontant et al. (2011); Leo et al. (2011).

bBarrionuevo and Burggren (1999); Michaelsson and Ho (2000); McKean et al. (2002); Zaar et al. (2007); van Timmeren et al. (2008).

${ }^{\mathrm{c}}$ Grabner and Pfitzer (1974) (pig); Kajstura et al. (1995) (dog; 74.5\% binucleated, 0.8\% trinucleated, $2 \%$ tetranucleated); Li et al. (1996) (rat; 1 d old, 3\% binucleated; $10 \mathrm{~d}$ old, $91 \%$ binucleated); Olivetti et al. (1996) (human; 25.5\% binucleated, $0.4 \%$ trinucleated, $0.1 \%$ tetranucleated); Soonpaa et al. (1996) (mouse); Burrell et al. (2003) (sheep; 83\% binucleated at $4 \mathrm{~d}$ of age; 92\% binucleated at 4-6 wk of age); Wills et al. (2008) (zebrafish); Botting et al. (2012); Mahmoud and Porrello (2012).

${ }^{\mathrm{d}}$ Poss et al. (2002); Raya et al. (2003).

${ }^{\mathrm{e}}$ Becker et al. (1974); Oberpriller and Oberpriller (1974); Oberpriller et al. (1988); Flink (2002).

${ }^{\mathrm{f}}$ Andersen et al. (2005).

${ }^{\mathrm{g}}$ Porrello et al. (2011).

tribute to CM regeneration during normal aging (Hsieh et al. 2007). The capacity for regeneration appears to be associated with age, because the neonatal mouse heart retains the ability for regeneration after resection of $\sim 15 \%$ of the apical ventricular tissue at $1 \mathrm{~d}$ of age (Porrello et al. 2011). Cardiac regeneration is likely due to dedifferentiation and subsequent proliferation of preexisting CMs rather than proliferation from a distinct stem cell population (Porrello et al. 2011). The ability of the mouse heart to regen- erate, however, is short-lived, because 7-d-old mice were unable to regenerate the myocardium and instead developed a significant fibrotic response after apical resection, similar to the wound healing process in both adult mice and humans (Porrello et al. 2011). Stimulation of molecular pathways involved in regeneration, such as by injection of neuregulin-1 into adult mice to activate the NRG1/ErbB4 pathway, may promote regeneration in differentiated, mononucleated cardiomyocytes (Bersell et al. 2009). 
J.C. Garbern et al.

Both mice and rats have been used in hundreds of studies to evaluate therapeutic approaches to healing the heart postinjury. Myocardial infarct models are frequently used, which typically involve occlusion of the left anterior descending artery to create an infarct (Huang et al. 2006; Borst et al. 2011). Therapeutic approaches have ranged from application of a cardiac patch (Kellar et al. 2001) to implantation of biomaterials (Landa et al. 2008) to transplantation of genetically modified cells (Qian et al. 2012). Parameters used to evaluate a therapeutic response include microvessel density (as quantified by histology [Mattfeldt and Mall 1987]), perfusion (via a fluorescent microsphere approach [Hale et al. 1986] or positron emission tomography [PET] [Vaquero et al. 2012]), morphometric analysis of tissue dimensions (Anversa et al. 1985), or cardiac function (via echocardiography [Liu and Rigel 2009] or cardiac MRI [van Laake et al. 2007a]). The majority of published studies show a statistically significant improvement in at least one of these parameters, although this may only be early and transient (van Laake et al. 2007b), and the implications for effectiveness and safety in human use remain to be determined for most of these approaches.

Guinea pigs were used to evaluate whether transplanted human ESC-derived CMs (hESCCMs) would couple with native CMs to provide synchronous contraction of the grafted heart to minimize the risk of arrhythmias (Shiba et al. 2012). With a baseline heart rate between 200 and 250 beats per minute (bpm), guinea pigs were selected over smaller rodents because the rapid heart rate of mice $(600 \mathrm{bpm})$ and rats (400 bpm) may make it impossible for the human CM to engraft properly. The hESCCMs were capable of 1:1 host-graft coupling, and transplantation of hESC-CMs into injured hearts resulted in a reduced risk of arrhythmias compared with untreated injured hearts.

\section{Large Nonhuman Mammals}

Larger animals such as dogs, sheep, pigs, or nonhuman primates have been used for testing of preclinical therapeutic approaches because of their larger heart sizes and closer semblance to human cardiac physiology, although their larger sizes can make them logistically and financially more challenging (Yarbrough and Spinale 2003). A meta-analysis of stem cell therapy approaches to treat ischemic heart disease in dogs, sheep, and pigs concluded that large animal models show comparable improvement in ejection fraction to similarly designed clinical trials in humans (van der Spoel et al. 2011).

Dogs have been used to evaluate therapeutic approaches following ischemic injury via occlusion of a coronary artery (Linke et al. 2005). However, unlike humans, canine hearts have a robust collateral circulation that can make it difficult to achieve a consistent degree of ischemic injury between animals using this technique (Yarbrough and Spinale 2003). In contrast, sheep and pigs have minimal collateral circulation in their coronary artery anatomy, making them more representative models of human ischemic myocardium (Yarbrough and Spinale 2003). The comparable heart sizes of sheep and pigs to humans also make them valuable for testing replacement heart valves or catheter-based therapies such as stent placement (Suzuki et al. 2011).

Nonhuman primates are another potential model system given their genetic similarity to humans. Human ESCs committed to a cardiac lineage were injected into the hearts of immunosuppressed rhesus monkeys after myocardial infarction (Blin et al. 2010). After 2 mo, the ESCs differentiated into ventricular CMs and repopulated $\sim 20 \%$ of the scar region (Blin et al. 2010). In another study, rhesus monkeys also were used to evaluate the safety and risk of teratoma formation after implantation of an epicardial patch following myocardial infarct (Bel et al. 2010). When committed to a cardiac lineage as identified by expression of stage-specific embryonic antigen-1 (SSEA-1), there was no evidence of teratoma formation at $2 \mathrm{mo}$ postimplantation (Bel et al. 2010). However, when ESCs were not sorted based on SSEA-1 status, there was a risk of microteratoma formation in the scar region, possibly from SSEA-1negative cells that retained pluripotent potential (Blin et al. 2010). 


\section{Human Studies}

Model systems of cardiac regeneration are used as precursors to clinical trials in humans. In addition to clinical trials, lessons from embryonic heart development can provide insight on cardiac regeneration in adult tissues (Mercola et al. 2011; Martin-Puig et al. 2012). Furthermore, research in human ESCs and inducible pluripotent cells has contributed to our understanding of the molecular mechanisms of disease and regenerative ability of human cells (Chien 2008).

Although a full discussion of clinical trials of cardiac regeneration and repair in humans is beyond the scope of this article, it is worth noting that evidence for the native regenerative capacity of human cardiac tissue has been identified recently (Laflamme et al. 2002; Quaini et al. 2002; Deb et al. 2003; Bergmann et al. 2009). As therapeutic approaches are developed to restore cardiac function, it will be necessary to identify noninvasive methods of quantifying effective regeneration of cardiac tissue (van Slochteren et al. 2012).

Partial restoration of myocardial function after disease and/or injury has been possible because of engineered devices such as stents, pacemakers, defibrillators, or ventricular assist devices. In addition, whole heart transplantation has prolonged the lives of many patients in whom surgical repair of their own heart was unfeasible, although the posttransplant course is complicated by chronic immune suppression or organ rejection (LaRosa et al. 2011). Current research is focused on the development of new strategies to augment the native regenerative ability of the human heart to result in clinically significant improvement in heart function after injury or disease (Clifford et al. 2012; Makkar et al. 2012).

\section{CONCLUSIONS}

Model systems have made significant contributions to our knowledge of cardiovascular regenerative biology. Furthermore, disease models have allowed us to perform preclinical studies to test therapeutic approaches to restore cardiac function following injury or disease. Future work should aim to further elucidate our understanding of human cardiac regenerative potential as well as to develop improved methods that can be used in the clinical setting to heal the human heart after injury.

\section{REFERENCES}

${ }^{*}$ Reference is also in this collection.

Andersen JB, Rourke BC, Caiozzo VJ, Bennett AF, Hicks JW. 2005. Physiology: Postprandial cardiac hypertrophy in pythons. Nature 434: 37-38.

Anversa P, Beghi C, Kikkawa Y, Olivetti G. 1985. Myocardial response to infarction in the rat. Morphometric measurement of infarct size and myocyte cellular hypertrophy. Am J Pathol 118: 484-492.

Ausoni S, Sartore S. 2009. From fish to amphibians to mammals: In search of novel strategies to optimize cardiac regeneration. J Cell Biol 184: 357-364.

Badylak SF, Weiss DJ, Caplan A, Macchiarini P. 2012. Engineered whole organs and complex tissues. Lancet 379: 943-952.

Bakker ML, Christoffels VM, Moorman AF. 2010. The cardiac pacemaker and conduction system develops from embryonic myocardium that retains its primitive phenotype. J Cardiovasc Pharmacol 56: 6-15.

Barile L, Messina E, Giacomello A, Marban E. 2007. Endogenous cardiac stem cells. Prog Cardiovasc Dis 50: $31-48$.

Barrionuevo WR, Burggren WW. 1999. $\mathrm{O}_{2}$ consumption and heart rate in developing zebrafish (Danio rerio): Influence of temperature and ambient $\mathrm{O}_{2}$. Am J Physiol 276: R505-R513.

Becker RO, Chapin S, Sherry R. 1974. Regeneration of the ventricular myocardium in amphibians. Nature 248: $145-147$.

Bel A, Planat-Bernard V, Saito A, Bonnevie L, Bellamy V, Sabbah L, Bellabas L, Brinon B, Vanneaux V, Pradeau P, et al. 2010. Composite cell sheets: A further step toward safe and effective myocardial regeneration by cardiac progenitors derived from embryonic stem cells. Circulation 122: S118-S123.

Beltrami AP, Barlucchi L, Torella D, Baker M, Limana F, Chimenti S, Kasahara H, Rota M, Musso E, Urbanek K, et al. 2003. Adult cardiac stem cells are multipotent and support myocardial regeneration. Cell 114: 763-776.

Bergmann O, Bhardwaj RD, Bernard S, Zdunek S, BarnabeHeider F, Walsh S, Zupicich J, Alkass K, Buchholz BA, Druid H, et al. 2009. Evidence for cardiomyocyte renewal in humans. Science 324: 98-102.

Bernstein HS, Srivastava D. 2012. Stem cell therapy for cardiac disease. Pediatr Res 71: 491-499.

Bersell K, Arab S, Haring B, Kuhn B. 2009. Neuregulin1/ ErbB4 signaling induces cardiomyocyte proliferation and repair of heart injury. Cell 138: 257-270.

Blin G, Nury D, Stefanovic S, Neri T, Guillevic O, Brinon B, Bellamy V, Rucker-Martin C, Barbry P, Bel A, et al. 2010. 


\section{J.C. Garbern et al.}

A purified population of multipotent cardiovascular progenitors derived from primate pluripotent stem cells engrafts in postmyocardial infarcted nonhuman primates. $J$ Clin Invest 120: 1125-1139.

Borisov AB. 1999. Regeneration of skeletal and cardiac muscle in mammals: Do nonprimate models resemble human pathology? Wound Repair Regen 7: 26-35.

Borst O, Ochmann C, Schonberger T, Jacoby C, Stellos K, Seizer P, Flogel U, Lang F, Gawaz M. 2011. Methods employed for induction and analysis of experimental myocardial infarction in mice. Cell Physiol Biochem 28: 1-12.

Botting K, Wang K, Padhee M, McMillen I, SummersPearce B, Rattanatray L, Cutri N, Posterino G, Brooks D, Morrison J. 2012. Early origins of heart disease: Low birth weight and determinants of cardiomyocyte endowment. Clin Exp Pharmacol Physiol 39: 814-823.

Braam SR, Tertoolen L, van de Stolpe A, Meyer T, Passier R, Mummery CL. 2010. Prediction of drug-induced cardiotoxicity using human embryonic stem cell-derived cardiomyocytes. Stem Cell Res 4: 107-116.

Breymann C, Schmidt D, Hoerstrup SP. 2006. Umbilical cord cells as a source of cardiovascular tissue engineering. Stem Cell Rev 2: 87-92.

Brockes JP, Kumar A. 2002. Plasticity and reprogramming of differentiated cells in amphibian regeneration. Nat Rev Mol Cell Biol 3: 566-574.

Brockes J, Kumar A. 2008. Comparative aspects of animal regeneration. Annu Rev Cell Dev Biol 24: 525-549.

Buja LM, Vela D. 2008. Cardiomyocyte death and renewal in the normal and diseased heart. Cardiovasc Pathol 17: 349-374.

Bunker AK, Laughlin MH. 2010. Influence of exercise and perivascular adipose tissue on coronary artery vasomotor function in a familial hypercholesterolemic porcine atherosclerosis model. J Appl Physiol 108: 490-497.

Burrell JH, Boyn AM, Kumarasamy V, Hsieh A, Head SI, Lumbers ER. 2003. Growth and maturation of cardiac myocytes in fetal sheep in the second half of gestation. Anat Rec A Discov Mol Cell Evol Biol 274: 952-961.

Cerbai E, Sartiani L, De Paoli P, Mugelli A. 2000. Isolated cardiac cells for electropharmacological studies. Pharmacol Res 42: 1-8.

Chien KR. 2008. Regenerative medicine and human models of human disease. Nature 453: 302-305.

Chung BG, Lee KH, Khademhosseini A, Lee SH. 2012. Microfluidic fabrication of microengineered hydrogels and their application in tissue engineering. Lab Chip 12: $45-59$.

Claycomb WC, Lanson NA Jr, Stallworth BS, Egeland DB, Delcarpio JB, Bahinski A, Izzo NJ Jr. 1998. HL-1 cells: A cardiac muscle cell line that contracts and retains phenotypic characteristics of the adult cardiomyocyte. Proc Natl Acad Sci 95: 2979-2984.

Clifford DM, Fisher SA, Brunskill SJ, Doree C, Mathur A, Watt S, Martin-Rendon E. 2012. Stem cell treatment for acute myocardial infarction. Cochrane Database Syst Rev 2: CD006536.

Curtis MW, Russell B. 2011. Micromechanical regulation in cardiac myocytes and fibroblasts: Implications for tissue remodeling. Pflugers Arch 462: 105-117.
Davidson MM, Nesti C, Palenzuela L, Walker WF, Hernandez E, Protas L, Hirano M, Isaac ND. 2005. Novel cell lines derived from adult human ventricular cardiomyocytes. J Mol Cell Cardiol 39: 133-147.

Davis L, Roullet JB, Thornburg KL, Shokry M, Hohimer AR, Giraud GD. 2002. Augmentation of coronary conductance in adult sheep made anaemic during fetal life. $J$ Physiol 547: 53-59.

Deb A, Wang S, Skelding KA, Miller D, Simper D, Caplice NM. 2003. Bone marrow-derived cardiomyocytes are present in adult human heart: A study of gendermismatched bone marrow transplantation patients. Circulation 107: 1247-1249.

de la Grandmaison GL, Clairand I, Durigon M. 2001. Organ weight in 684 adult autopsies: New tables for a Caucasoid population. Forensic Sci Int 119: 149-154.

Eglen R, Reisine T. 2011. Primary cells and stem cells in drug discovery: Emerging tools for high-throughput screening. Assay Drug Dev Technol 9: 108-124.

Ellingsen A, Davidoff AJ, Prasad SK, Berger HG, Springhorn JP, Marsh JD, Kelly RA, Smith TW. 1993. Adult rat ventricular myocytes cultured in defined medium: Phenotype and electromechanical function. Am J Physiol Heart Circ Physiol 265: H747-H754.

Engelmayr GC Jr, Cheng M, Bettinger CJ, Borenstein JT, Langer R, Freed LE. 2008. Accordion-like honeycombs for tissue engineering of cardiac anisotropy. Nat Mater 7: $1003-1010$.

Ferrier GR, Howlett SE. 2005. Pretreatment with pinacidil promotes arrhythmias in an isolated tissue model of cardiac ischemia and reperfusion. J Pharmacol Exp Ther 313: 823-830.

Fidkowski C, Kaazempur-Mofrad MR, Borenstein J, Vacanti JP, Langer R, Wang Y. 2005. Endothelialized microvasculature based on a biodegradable elastomer. Tissue Eng 11: 302-309.

Field LJ. 1988. Atrial natriuretic factor-SV40 Tantigen transgenes produce tumors and cardiac arrhythmias in mice. Science 239: 1029-1033.

Flink IL. 2002. Cell cycle reentry of ventricular and atrial cardiomyocytes and cells within the epicardium following amputation of the ventricular apex in the axolotl, Amblystoma mexicanum: Confocal microscopic immunofluorescent image analysis of bromodeoxyuridine-labeled nuclei. Anat Embryol (Berl) 205: 235-244.

Galvao V, Miranda JG, Ribeiro-dos-Santos R. 2008. Development of a two-dimensional agent-based model for chronic chagasic cardiomyopathy after stem cell transplantation. Bioinformatics 24: 2051-2056.

Goldsmith MI, Iovine MK, O’Reilly-Pol T, Johnson SL. 2006. A developmental transition in growth control during zebrafish caudal fin development. Dev Biol 296: 450457.

González-Rosa JM, Mercader N. 2012. Cryoinjury as a myocardial infarction model for the study of cardiac regeneration in the zebrafish. Nat Protoc 7: 782-788.

Goumans MJ, de Boer TP, Smits AM, van Laake LW, van Vliet P, Metz CH, Korfage TH, Kats KP, Hochstenbach R, Pasterkamp G, et al. 2008. TGF- $\beta 1$ induces efficient differentiation of human cardiomyocyte progenitor cells into functional cardiomyocytes in vitro. Stem Cell Res 1: 138-149. 
Gourdie RG, Mima T, Thompson RP, Mikawa T. 1995. Terminal diversification of the myocyte lineage generates Purkinje fibers of the cardiac conduction system. Development 121: 1423-1431.

Grabner W, Pfitzer P. 1974. Number of nuclei in isolated myocardial cells of pigs. Virchows Arch B Cell Pathol 15: 279-294.

Grashow JS, Yoganathan AP, Sacks MS. 2006. Biaixal stressstretch behavior of the mitral valve anterior leaflet at physiologic strain rates. Ann Biomed Eng 34: 315-325.

Grosberg A, Alford PW, McCain ML, Parker KK. 2011. Ensembles of engineered cardiac tissues for physiological and pharmacological study: Heart on a chip. Lab Chip 11: $4165-4173$.

Guo L, Abrams RM, Babiarz JE, Cohen JD, Kameoka S, Sanders MJ, Chiao E, Kolaja KL. 2011. Estimating the risk of drug-induced proarrhythmia using human induced pluripotent stem cell-derived cardiomyocytes. Toxicol Sci 123: 281-289.

Hale SL, Vivaldi MT, Kloner RA. 1986. Fluorescent microspheres: A new tool for visualization of ischemic myocardium in rats. Am J Physiol 251: H863-H868.

Hasenfuss G. 1998. Animal models of human cardiovascular disease heart failure and hypertrophy. Cardiovasc Res 39: $60-76$.

Herron TJ, Lee P, Jalife J. 2012. Optical imaging of voltage and calcium in cardiac cells and tissues. Circ Res 110: 609-623.

Houser SR, Margulies KB, Murphy AM, Spinale FG, Francis GS, Prabhu SD, Rockman HA, Kass DA, Molkentin JD, Sussman MA, et al. 2012. Animal models of heart failure: A scientific statement from the American Heart Association. Circ Res 111: 131-150.

Hsieh PC, Segers VF, Davis ME, MacGillivray C, Gannon J, Molkentin JD, Robbins J, Lee RT. 2007. Evidence from a genetic fate-mapping study that stem cells refresh adult mammalian cardiomyocytes after injury. Nat Med 13: 970-974.

Huang NF, Sievers RE, Park JS, Fang Q, Li S, Lee RJ. 2006. A rodent model of myocardial infarction for testing the efficacy of cells and polymers for myocardial reconstruction. Nat Protoc 1: 1596-1609.

Ionescu-Zanetti C, Shaw RM, Seo J, Jan YN, Jan LY, Lee LP. 2005. Mammalian electrophysiology on a microfluidic platform. Proc Natl Acad Sci 102: 9112-9117.

Jopling C, Sleep E, Raya M, Marti M, Raya A, Izpisua Belmonte JC. 2010. Zebrafish heart regeneration occurs by cardiomyocyte dedifferentiation and proliferation. Nature 464: 606-609.

Kajstura J, Zhang X, Liu Y, Szoke E, Cheng W, Olivetti G, Hintze TH, Anversa P. 1995. The cellular basis of pacinginduced dilated cardiomyopathy. Myocyte cell loss and myocyte cellular reactive hypertrophy. Circulation 92: 2306-2317.

Keenan CM, Vidal JD. 2006. Standard morphologic evaluation of the heart in the laboratory dog and monkey. Toxicol Pathol 34: 67-74.

Kellar RS, Landeen LK, Shepherd BR, Naughton GK, Ratcliffe A, Williams SK. 2001. Scaffold-based three-dimensional human fibroblast culture provides a structural matrix that supports angiogenesis in infarcted heart tissue. Circulation 104: 2063-2068.

Kerckhoffs RC, McCulloch AD, Omens JH, Mulligan LJ. 2009. Effects of biventricular pacing and scar size in a computational model of the failing heart with left bundle branch block. Med Image Anal 13: 362-369.

Kikuchi K, Holdway JE, Werdich AA, Anderson RM, Fang Y, Egnaczyk GF, Evans T, Macrae CA, Stainier DY, Poss KD. 2010. Primary contribution to zebrafish heart regeneration by gata $4^{+}$cardiomyocytes. Nature 464: 601-605.

Kim DK, Choi E, Song BW, Cha MJ, Ham O, Lee SY, Lee CY, Park JH, Song H, Hwang KC. 2012. Differentially regulated functional gene clusters identified in early hypoxic cardiomyocytes. Mol Biol Rep 39: 9549-9556.

Kirkpatrick CJ, Fuchs S, Unger RE. 2011. Co-culture systems for vascularization-Learning from nature. Adv Drug Deliv Rev 63: 291-299.

Kitta K, Clement SA, Remeika J, Blumberg JB, Suzuki YJ. 2001. Endothelin-1 induces phosphorylation of GATA-4 transcription factor in the HL-1 atrial-muscle cell line. Biochem J 359: 375-380.

Klauke N, Smith G, Cooper JM. 2007. Microfluidic systems to examine intercellular coupling of pairs of cardiac myocytes. Lab Chip 7: 731-739.

Kofidis T, Lenz A, Boublik J, Akhyari P, Wachsmann B, Stahl KM, Haverich A, Leyh RG. 2003. Bioartificial grafts for transmural myocardial restoration: A new cardiovascular tissue culture concept. Eur J Cardiothorac Surg 24: 906-911.

Laflamme MA, Myerson D, Saffitz JE, Murry CE. 2002. Evidence for cardiomyocyte repopulation by extracardiac progenitors in transplanted human hearts. Circ Res 90: 634-640.

Lafontant PJ, Burns AR, Grivas JA, Lesch MA, Lala TD, Reuter SP, Field LJ, Frounfelter TD. 2011. The giant Danio(D. aequipinnatus) as a model of cardiac remodeling and regeneration. Anat Rec (Hoboken) 295: 234-248.

Landa N, Miller L, Feinberg MS, Holbova R, Shachar M, Freeman I, Cohen S, Leor J. 2008. Effect of injectable alginate implant on cardiac remodeling and function after recent and old infarcts in rat. Circulation 117: 1388-1396.

LaRosa C, Baluarte HJ, Meyers KE. 2011. Outcomes in pediatric solid-organ transplantation. Pediatr Transplant 15: $128-141$.

Larson SG. 1978. Scaling of organ weights in Macaca arctoides. Am J Phys Anthropol 49: 95-102.

Laube F, Heister M, Scholz C, Borchardt T, Braun T. 2006. Re-programming of newt cardiomyocytes is induced by tissue regeneration. J Cell Sci 119: 4719-4729.

* Laugwitz KL. 2013. Stem cell models of human heart disease. Cold Spring Harb Perspect Med doi: 10/1101.cshperspect.a014027.

Leo C, Sala V, Morello M, Chiribiri A, Riess I, Mancardi D, Schiaffino S, Ponzetto C, Crepaldi T. 2011. Activated Met signalling in the developing mouse heart leads to cardiac disease. PLoS ONE 6: e14675.

Leor J, Aboulafia-Etzion S, Dar A, Shapiro L, Barbash IM, Battler A, Granot Y, Cohen S. 2000. Bioengineered cardiac grafts: A new approach to repair the infarcted myocardium? Circulation 102 (Suppl 3): III56-III61. 
J.C. Garbern et al.

Lepilina A, Coon AN, Kikuchi K, Holdway JE, Roberts RW, Burns CG, Poss KD. 2006. A dynamic epicardial injury response supports progenitor cell activity during zebrafish heart regeneration. Cell 127: 607-619.

Li F, Wang X, Capasso JM, Gerdes AM. 1996. Rapid transition of cardiac myocytes from hyperplasia to hypertrophy during postnatal development. J Mol Cell Cardiol 28: 1737-1746.

Li RK, Yau TM, Weisel RD, Mickle DA, Sakai T, Choi A, Jia ZQ. 2000. Construction of a bioengineered cardiac graft. J Thorac Cardiovasc Surg 119: 368-375.

Li XH, Fu YH, Lin QX, Liu ZY, Shan ZX, Deng CY, Zhu JN, Yang M, Lin SG, Li Y, et al. 2012. Induced bone marrow mesenchymal stem cells improve cardiac performance of infarcted rat hearts. Mol Biol Rep 39: 1333-1342.

Liem LK, Simard JM, Song Y, Tewari K. 1995. The patch clamp technique. Neurosurgery 36: 382-392.

Lien CL, Harrison MR, Tuan TL, Starnes VA. 2012. Heart repair and regeneration: Recent insights from zebrafish studies. Wound Repair Regen 20: 638-646.

Linke A, Müller P, Nurzynsky D, Casarsa C, Torella D, Nascimbene A, Castaldo C, Cascapera S, Böhm M, Quaini F, et al. 2005. Stem cells in the dog heart are self-renewing, clonogenic, and multipotent and regenerate infarcted myocardium, improving cardiac function. Proc Natl Acad Sci 102: 8966-8971.

Liu J, Rigel DF. 2009. Echocardiographic examination in rats and mice. Methods Mol Biol 573: 139-155.

Lu J, Wang HZ, Jia Z, Zuckerman J, Lu Z, Guo Y, Boink GJ, Brink PR, Robinson RB, Entcheva E, et al. 2012. Improving cardiac conduction with a skeletal muscle sodium channel by gene and cell therapy. J Cardiovasc Pharmacol 60: $88-99$.

Mahmoud AI, Porrello ER. 2012. Turning back the cardiac regenerative clock: Lessons from the neonate. Trends Cardiovasc Med 22: 128-133.

Makkar RR, Smith RR, Cheng K, Malliaras K, Thomson LE, Berman D, Czer LS, Marban L, Mendizabal A, Johnston PV, et al. 2012. Intracoronary cardiosphere-derived cells for heart regeneration after myocardial infarction (CADUCEUS): A prospective randomised phase 1 trial. Lancet 379: 895-904.

Maltsev VA, Wobus AM, Rohwedel J, Bader M, Hescheler J. 1994. Cardiomyocytes differentiated in vitro from embryonic stem cells developmentally express cardiac-specific genes and ionic currents. Circ Res 75: 233-244.

Martin-Puig S, Fuster V, Torres M. 2012. Heart repair: From natural mechanisms of cardiomyocyte production to the design of new cardiac therapies. Ann NY Acad Sci 1254: 71-81.

Mattfeldt T, Mall G. 1987. Growth of capillaries and myocardial cells in the normal rat heart. J Mol Cell Cardiol 19: 1237-1246.

McKean T, Li G, Wei K. 2002. Cardiac effects of hypoxia in the neotenous tiger salamander Ambystoma tigrinum. $J$ Exp Biol 205: 1725-1734.

Mercola M, Ruiz-Lozano P, Schneider MD. 2011. Cardiac muscle regeneration: Lessons from development. Genes Dev 25: 299-309.

Messina E, De Angelis L, Frati G, Morrone S, Chimenti S, Fiordaliso F, Salio M, Battaglia M, Latronico MV,
Coletta M, et al. 2004. Isolation and expansion of adult cardiac stem cells from human and murine heart. Circ Res 95: 911-921.

Michaelsson M, Ho S. 2000. Congenital heart malformations in mammals: An illustrated text. Imperial College Press, London.

Mitcheson JS, Hancox JC, Levi AJ. 1998. Cultured adult cardiac myocytes: Future applications, culture methods morphological and electrophysiological properties. Cardiovasc Res 39: 280-300.

Miyagawa S, Sawa Y, Sakakida S, Taketani S, Kondoh H, Memon IA, Imanishi Y, Shimizu T, Okano T, Matsuda H. 2005. Tissue cardiomyoplasty using bioengineered contractile cardiomyocyte sheets to repair damaged myocardium: Their integration with recipient myocardium. Transplantation 80: 1586-1595.

Mummery C, Ward D, van den Brink CE, Bird SD, Doevendans PA, Opthof T, Brutel de la Riviere A, Tertoolen L, van der Heyden M, Pera M. 2002. Cardiomyocyte differentiation of mouse and human embryonic stem cells. J Anat 200: $233-242$.

Mummery C, Ward-van Oostwaard D, Doevendans P, Spijker R, van den Brink S, Hassink R, van der Heyden M, Opthof T, Pera M, de la Riviere AB, et al. 2003. Differentiation of human embryonic stem cells to cardiomyocytes: Role of coculture with visceral endoderm-like cells. Circulation 107: 2733-2740.

Neely JR, Rovetto MJ, Whitmer JT, Morgan HE. 1973. Effects of ischemia on function and metabolism of the isolated working rat heart. Am J Physiol 225: 651-658.

Neff AW, Dent AE, Armstrong JB. 1996. Heart development and regeneration in urodeles. Int J Dev Biol 40: 719-725.

Newmark PA, Sanchez Alvarado A. 2002. Not your father's planarian: A classic model enters the era of functional genomics. Nat Rev Genet 3: 210-219.

Nguyen SV, Claycomb WC. 1999. Hypoxia regulates the expression of the adrenomedullin and HIF-1 genes in cultured HL-1 cardiomyocytes. Biochem Biophys Res Commun 265: 382-386.

Nishida K, Michael G, Dobrev D, Nattel S. 2010. Animal models for atrial fibrillation: Clinical insights and scientific opportunities. Europace 12: 160-172.

Nistri S, Pini A, Sassoli C, Squecco R, Francini F, Formigli L, Bani D. 2012. Relaxin promotes growth and maturation of mouse neonatal cardiomyocytes in vitro: Clues for cardiac regeneration. J Cell Mol Med 16: 507-519.

Oberpriller JO, Oberpriller JC. 1974. Response of the adult newt ventricle to injury. J Exp Zool 187: 249-253.

Oberpriller JO, Oberpriller JC, Arefyeva AM, Mitashov VI, Carlson BM. 1988. Nuclear characteristics of cardiac myocytes following the proliferative response to mincing of the myocardium in the adult newt, Notophthalmus viridescens. Cell Tissue Res 253: 619-624.

Oh H, Bradfute SB, Gallardo TD, Nakamura T, Gaussin V, Mishina Y, Pocius J, Michael LH, Behringer RR, Garry DJ, et al. 2003. Cardiac progenitor cells from adult myocardium: Homing differentiation and fusion after infarction. Proc Natl Acad Sci 100: 12313-12318.

Olivetti G, Cigola E, Maestri R, Corradi D, Lagrasta C, Gambert SR, Anversa P. 1996. Aging, cardiac hypertrophy and ischemic cardiomyopathy do not affect the 
proportion of mononucleated and multinucleated myocytes in the human heart. J Mol Cell Cardiol 28: 14631477.

Ou DB, He Y, Chen R, Teng JW, Wang HT, Zeng D, Liu XT, Ding L, Huang JY, Zheng QS. 2011. Three-dimensional co-culture facilitates the differentiation of embryonic stem cells into mature cardiomyocytes. J Cell Biochem 112: $3555-3562$.

Palatinus JA, Rhett JM, Gourdie RG. 2010. Translational lessons from scarless healing of cutaneous wounds and regenerative repair of the myocardium. J Mol Cell Cardiol 48: $550-557$.

Passier R, van Laake LW, Mummery CL. 2008. Stem-cellbased therapy and lessons from the heart. Nature 453: 322-329.

Patra C, Talukdar S, Novoyatleva T, Velagala SR, Muhlfeld C, Kundu B, Kundu SC, Engel FB. 2012. Silk protein fibroin from Antheraea mylitta for cardiac tissue engineering. Biomaterials 33: 2673-2680.

Peirce SM. 2008. Computational and mathematical modeling of angiogenesis. Microcirculation 15: 739-751.

Porrello ER, Mahmoud AI, Simpson E, Hill JA, Richardson JA, Olson EN, Sadek HA. 2011. Transient regenerative potential of the neonatal mouse heart. Science 331: 1078-1080.

Poss KD. 2007. Getting to the heart of regeneration in zebrafish. Semin Cell Dev Biol 18: 36-45.

Poss KD, Wilson LG, Keating MT. 2002. Heart regeneration in zebrafish. Science 298: 2188-2190.

Poupa O, Lindstrom L. 1983. Comparative and scaling aspects of heart and body weights with reference to blood supply of cardiac fibers. Comp Biochem Physiol A Comp Physiol 76: 413-421.

Qian L, Huang Y, Spencer CI, Foley A, Vedantham V, Liu L, Conway SJ, Fu JD, Srivastava D. 2012. In vivo reprogramming of murine cardiac fibroblasts into induced cardiomyocytes. Nature 485: 593-598.

Quaini F, Urbanek K, Beltrami AP, Finato N, Beltrami CA, Nadal-Ginard B, Kajstura J, Leri A, Anversa P. 2002. Chimerism of the transplanted heart. $N$ Engl J Med 346: 5-15.

Raake PW, Zhang X, Vinge LE, Brinks H, Gao E, Jaleel N, Li Y, Tang M, Most P, Dorn GW II, et al. 2012. Cardiac Gprotein-coupled receptor kinase 2 ablation induces a novel $\mathrm{Ca}^{2+}$ handling phenotype resistant to adverse alterations and remodeling after myocardial infarction. Circulation 125: 2108-2118.

Raya A, Koth CM, Buscher D, Kawakami Y, Itoh T, Raya RM, Sternik G, Tsai HJ, Rodriguez-Esteban C, IzpisuaBelmonte JC. 2003. Activation of Notch signaling pathway precedes heart regeneration in zebrafish. Proc Natl Acad Sci 100: 11889-11895.

Riquelme CA, Magida JA, Harrison BC, Wall CE, Marr TG, Secor SM, Leinwand LA. 2011. Fatty acids identified in the Burmese python promote beneficial cardiac growth. Science 334: 528-531.

Roy S, Gatien S. 2008. Regeneration in axolotls: A model to aim for! Exp Gerontol 43: 968-973.

Ruttkay-Nedecky I. 2004. Comparative dipolar electrocardiotopographic study of ventricular activation in Macaca mulatta monkeys and man. Physiol Res 53: 143-147.
Sanchez Alvarado A, Tsonis PA. 2006. Bridging the regeneration gap: Genetic insights from diverse animal models. Nat Rev Genet 7: 873-884.

Sartiani L, Bochet P, Cerbai E, Mugelli A, Fischmeister R. 2002. Functional expression of the hyperpolarization-activated, non-selective cation current I(f) in immortalized HL-1 cardiomyoctes. J Physiol 545: 81-92.

Sartiani L, Bettiol E, Stillitano F, Mugelli A, Cerbai E, Jaconi ME. 2007. Developmental changes in cardiomyocytes differentiated from human embryonic stem cells: A molecular and electrophysiological approach. Stem Cells 25: 1136-1144.

Sheikh F, Ouyang K, Campbell S, Lyon R, Chuang J, Fitzsimons D, Tangney J, Hidalgo C, Chung C, Cheng H, et al. 2012. Integrative mouse and computational models link altered myosin kinetics to early events in cardiac disease. $J$ Clin Invest 122: 1209-1221.

Shiba Y, Fernandes S, Zhu WZ, Filice D, Muskheli V, Kim J, Palpant NJ, Gantz J, Moyes KW, Reinecke H, et al. 2012. Human ES-cell-derived cardiomyocytes electrically couple and suppress arrhythmias in injured hearts. Nature 489: $322-325$.

Shimizu T, Yamato M, Isoi Y, Akutsu T, Setomaru T, Abe K, Kikuchi A, Umezu M, Okano T. 2002. Fabrication of pulsatile cardiac tissue grafts using a novel 3-dimensional cell sheet manipulation technique and temperature-responsive cell culture surfaces. Circ Res 90: e40.

Shin M, Ishii O, Sueda T, Vacanti JP. 2004. Contractile cardiac grafts using a novel nanofibrous mesh. Biomaterials 25: $3717-3723$.

Siepe M, Giraud MN, Pavlovic M, Receputo C, Beyersdorf F Menasche P, Carrel T, Tevaearai HT. 2006. Myoblast-seeded biodegradable scaffolds to prevent post-myocardial infarction evolution toward heart failure. $J$ Thorac Cardiovasc Surg 132: 124-131.

Singelyn JM, DeQuach JA, Seif-Naraghi SB, Littlefield RB, Schup-Magoffin PJ, Christman KL. 2009. Naturally derived myocardial matrix as an injectable scaffold for cardiac tissue engineering. Biomaterials 30: 5409-5416.

Singh BN, Koyano-Nakagawa N, Garry JP, Weaver CV. 2010. Heart of newt: A recipe for regeneration. J Cardiovasc Transl Res 3: 397-409.

Sirois E, Sun W. 2010. Computational evaluation of platelet activation induced by a bioprosthetic heart valve. Artif Organs 35: 157-165.

Smart N, Bollini S, Dube KN, Vieira JM, Zhou B, Davidson S, Yellon D, Riegler J, Price AN, Lythgoe MF, et al. 2011. De novo cardiomyocytes from within the activated adult heart after injury. Nature 474: 640-644.

Smith RR, Barile L, Cho HC, Leppo MK, Hare JM, Messina E, Giacomello A, Abraham MR, Marban E. 2007 Regenerative potential of cardiosphere-derived cells expanded from percutaneous endomyocardial biopsy specimens. Circulation 115: 896-908.

Smits AM, van Vliet P, Metz CH, Korfage T, Sluijter JP, Doevendans PA, Goumans MJ. 2009. Human cardiomyocyte progenitor cells differentiate into functional mature cardiomyocytes: An in vitro model for studying human cardiac physiology and pathophysiology. Nat Protoc 4: $232-243$.

Soares CP, Midlej V, de Oliveira ME, Benchimol M, Costa ML, Mermelstein C. 2012. 2D and 3D-organized 


\section{J.C. Garbern et al.}

cardiac cells shows differences in cellular morphology adhesion junctions presence of myofibrils and protein expression. PLoS ONE 7: e38147.

Soonpaa MH, Kim KK, Pajak L, Franklin M, Field LJ. 1996. Cardiomyocyte DNA synthesis and binucleation during murine development. Am J Physiol 271: H2183-H2189.

Steinhauser ML, Lee RT. 2011. Regeneration of the heart. EMBO Mol Med 3: 701-712.

Stevens KR, Kreutziger KL, Dupras SK, Korte FS, Regnier M, Muskheli V, Nourse MB, Bendixen K, Reinecke H, Murry CE. 2009. Physiological function and transplantation of scaffold-free and vascularized human cardiac muscle tissue. Proc Natl Acad Sci 106: 16568-16573.

Suzuki Y, Yeung AC, Ikeno F. 2011. The representative porcine model for human cardiovascular disease. J Biomed Biotechnol 2011: 195483.

Tiritilli A. 2001. DOCA-salts induce heart failure in the guinea pig. Eur J Heart Fail 3: 545-551.

Tulloch NL, Muskheli V, Razumova MV, Korte FS, Regnier M, Hauch KD, Pabon L, Reinecke H, Murry CE 2011. Growth of engineered human myocardium with mechanical loading and vascular coculture. Circ Res 109: $47-59$.

Usyk T, Omens J, McCulloch A. 2001. Regional septal dysfunction in a three-dimensional computational model of focal myofiber disarray. Am J Physiol Heart Circ Physiol 281: H506-H514.

van der Meer AD, Poot AA, Duits MH, Feijen J, Vermes I. 2009. Microfluidic technology in vascular research. J Biomed Biotechnol 2009: 823148.

van der Spoel TIG, Jansen of Lorkeers SJ, Agostoni P, van Belle E, Gyöngyösi M, Sluijter JPG, Cramer MJ, Doevendans PA, Chamuleau SAJ. 2011. Human relevance of preclinical studies in stem cell therapy: Systematic review and meta-analysis of large animal models of ischaemic heart disease. Cardiovasc Res 91: 649-658.

van Laake LW, Passier R, Monshouwer-Kloots J, Nederhoff MG, Ward-van Oostwaard D, Field LJ, van Echteld CJ, Doevendans PA, Mummery CL. 2007a. Monitoring of cell therapy and assessment of cardiac function using magnetic resonance imaging in a mouse model of myocardial infarction. Nat Protoc 2: 2551-2567.

van Laake LW, Passier R, Monshouwer-Kloots J, Verkleij AJ, Lips DJ, Freund C, den Ouden K, Ward-van Oostwaard D, Korving J, Tertoolen LG, et al. 2007b. Human embryonic stem cell-derived cardiomyocytes survive and mature in the mouse heart and transiently improve function after myocardial infarction. Stem Cell Res 1: 9-24.

van Slochteren FJ, Teske AJ, van der Spoel TI, Koudstaal S, Doevendans PA, Sluijter JP, Cramer MJ, Chamuleau SA. 2012. Advanced measurement techniques of regional myocardial function to assess the effects of cardiac regenerative therapy in different models of ischaemic cardiomyopathy. Eur Heart J Cardiovasc Imaging 13: 808-818.

van Timmeren MM, Gross ML, Hanke W, Klok PA, van Goor H, Stegeman CA, Bakker SJ. 2008. Oleic acid loading does not add to the nephrotoxic effect of albumin in an amphibian and chronic rat model of kidney injury. Nephrol Dial Transplant 23: 3814-3823. van Vliet P, Goumans MJ, Doevendans PA, Sluijter JP. 2012. Human cardiomyocyte progenitor cells: A short history of nearly everything. J Cell Mol Med 16: 1669-1673.

Vaquero JJ, Gao DW, Garcia-Villaba C, Bacharach S, Vanbrocklin H, Fang Q, Desco M, Lee R, Dae M. 2012. Approach to assessing myocardial perfusion in rats using static ${ }^{13} \mathrm{~N}$-ammonia images and a small-animal PET. Mol Imaging Biol 14: 541-545.

Vidarsson H, Hyllner J, Sartipy P. 2010. Differentiation of human embryonic stem cells to cardiomyocytes for in vitro and in vivo applications. Stem Cell Rev 6: 108-120.

Vidavalur R, Swarnakar S, Thirunavukkarasu M, Samuel SM, Maulik N. 2008. Ex vivo and in vivo approaches to study mechanisms of cardioprotection targeting ische$\mathrm{mia} /$ reperfusion (i/r) injury: Useful techniques for cardiovascular drug discovery. Curr Drug Discov Technol 5: 269-278.

von Gise A, Lin Z, Schlegelmilch K, Honor LB, Pan GM, Buck JN, Ma Q, Ishiwata T, Zhou B, Camargo FD, et al. 2012. YAP1 the nuclear target of Hippo signaling stimulates heart growth through cardiomyocyte proliferation but not hypertrophy. Proc Natl Acad Sci 109: 2394-2399.

Walsh S, Ponten A, Fleischmann BK, Jovinge S. 2010. Cardiomyocyte cell cycle control and growth estimation in vivo-An analysis based on cardiomyocyte nuclei. Cardiovasc Res 86: 365-373.

Walther G, Gekas J, Bertrand OF. 2009. Amniotic stem cells for cellular cardiomyoplasty: Promises and premises. Catheter Cardiovasc Interv 73: 917-924.

Wang J, Panakova D, Kikuchi K, Holdway JE, Gemberling M, Burris JS, Singh SP, Dickson AL, Lin YF, Sabeh MK, et al. 2011. The regenerative capacity of zebrafish reverses cardiac failure caused by genetic cardiomyocyte depletion. Development 138: 3421-3430.

Weymann A, Loganathan S, Takahashi H, Schies C, Claus B, Hirschberg K, Soos P, Korkmaz S, Schmack B, Karck M, et al. 2011. Development and evaluation of a perfusion decellularization porcine heart model-Generation of 3-dimensional myocardial neoscaffolds. Circ J 75: 852860.

White SM, Constantin PE, Claycomb WC. 2004. Cardiac physiology at the cellular level: Use of cultured HL-1 cardiomyocytes for studies of cardiac muscle cell structure and function. Am J Physiol Heart Circ Physiol 286: H823-H829.

Wills AA, Holdway JE, Major RJ, Poss KD. 2008. Regulated addition of new myocardial and epicardial cells fosters homeostatic cardiac growth and maintenance in adult zebrafish. Development 135: 183-192.

World Health Organization. 2011. Causes of death 2008: Summary tables. Health Statistics and Informatics Department, World Health Organization, Geneva.

Xu X, Colecraft HM. 2009. Primary culture of adult rat heart myocytes. J Vis Exp 16: 1308.

Yarbrough WM, Spinale FG. 2003. Large animal models of congestive heart failure: A critical step in translating basic observations into clinical applications. J Nucl Cardiol 10: 77-86.

Ye KY, Black LD III. 2011. Strategies for tissue engineering cardiac constructs to affect functional repair following myocardial infarction. J Cardiovasc Transl Res 4: 575591. 
Model Systems for Cardiac Regeneration

Ye Sheng X, Qu Y, Dan P, Lin E, Korthout L, Bradford A, Hove-Madsen L, Sanatani S, Tibbits GF. 2011. Isolation and characterization of atrioventricular nodal cells from neonate rabbit heart. Circ Arrhythm Electrophysiol 4: $936-946$.

Yoshida Y, Yamanaka S. 2011. iPS cells: A source of cardiac regeneration. J Mol Cell Cardiol 50: 327-332.

Zaar M, Overgaard J, Gesser H, Wang T. 2007. Contractile properties of the functionally divided python heart: Two sides of the same matter. Comp Biochem Physiol A Mol Integr Physiol 146: 163-173.

Zaragoza C, Gomez-Guerrero C, Martin-Ventura JL, Blanco-Colio L, Lavin B, Mallavia B, Tarin C, Mas S, Ortiz A,
Egido J. 2011. Animal models of cardiovascular diseases. J Biomed Biotechnol 2011: 497841.

Zaruba MM, Field LJ. 2008. The mouse as a model system to study cardiac regeneration. Drug Discov Today Dis Models 5: $165-171$.

Zhang B, Xiao Y, Hsieh A, Thavandiran N, Radisic M. 2011. Micro- and nanotechnology in cardiovascular tissue engineering. Nanotechnology 22: 494003.

Zimmermann WH, Didie M, Doker S, Melnychenko I, Naito H, Rogge C, Tiburcy M, Eschenhagen T. 2006. Heart muscle engineering: An update on cardiac muscle replacement therapy. Cardiovasc Res 71: 419429. 


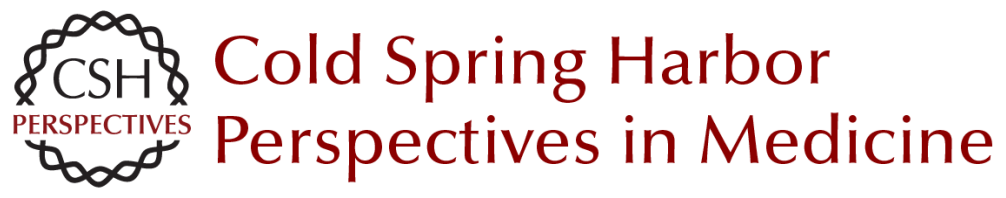

\section{Model Systems for Cardiovascular Regenerative Biology}

Jessica C. Garbern, Christine L. Mummery and Richard T. Lee

Cold Spring Harb Perspect Med 2013; doi: 10.1101/cshperspect.a014019

Subject Collection The Biology of Heart Disease

The Genetic Basis of Aortic Aneurysm Mark E. Lindsay and Harry C. Dietz

\section{Personalized Genomes and Cardiovascular \\ Disease \\ Kiran Musunuru}

Complex Genetics and the Etiology of Human Congenital Heart Disease

Bruce D. Gelb and Wendy K. Chung

Genetic Networks Governing Heart Development Ashley J. Waardenberg, Mirana Ramialison, Romaric Bouveret, et al.

Heart Fields and Cardiac Morphogenesis Robert G. Kelly, Margaret E. Buckingham and Antoon F. Moorman

Regenerative Medicine: Transforming the Drug Discovery and Development Paradigm Sotirios K. Karathanasis

Myocardial Tissue Engineering: In Vitro Models Gordana Vunjak Novakovic, Thomas Eschenhagen and Christine Mummery

Pluripotent Stem Cell Models of Human Heart

Disease

Alessandra Moretti, Karl-Ludwig Laugwitz, Tatjana

Dorn, et al.
Cardiac Cell Lineages that Form the Heart Sigolène M. Meilhac, Fabienne Lescroart, Cédric Blanpain, et al.

Synthetic Chemically Modified mRNA (modRNA):

Toward a New Technology Platform for

Cardiovascular Biology and Medicine Kenneth R. Chien, Lior Zangi and Kathy O. Lui

Next-Generation Models of Human Cardiogenesis via Genome Editing

Xiaojun Lian, Jiejia Xu, Jinsong Li, et al.

How to Make a Heart Valve: From Embryonic Development to Bioengineering of Living Valve Substitutes

Donal MacGrogan, Guillermo Luxán, Anita Driessen-Mol, et al.

Insights into the Genetic Structure of Congenital Heart Disease from Human and Murine Studies on Monogenic Disorders Terence Prendiville, Patrick Y. Jay and William T. $\mathrm{Pu}$

Cardiovascular Drug Discovery: A Perspective from a Research-Based Pharmaceutical Company G. Gromo, J. Mann and J.D. Fitzgerald

Genetics and Disease of Ventricular Muscle Diane Fatkin, Christine E. Seidman and Jonathan G. Seidman

Embryonic Heart Progenitors and Cardiogenesis Thomas Brade, Luna S. Pane, Alessandra Moretti, et al.

For additional articles in this collection, see http://perspectivesinmedicine.cshlp.org/cgi/collection/ 